\title{
Strategi Pengembangan UMKM Keris Kabupaten Sumenep
}

\author{
Mahendra Wardhana ${ }^{1}$, Adi Soeprijanto ${ }^{2}$, Harus Laksana Guntur ${ }^{3}$, Imam Abadi ${ }^{4}$, \\ Mohammad Herli ${ }^{5}$ \\ 1,2,3,4 Institut Teknologi Sepuluh Nopember, Surabaya 60111 Indonesia \\ ${ }^{5}$ Program Studi Akuntansi Fakultas Ekonomi dan Bisnis Universitas Wiraraja, Sumenep 69451 Indonesia \\ mahendra@interior.its.ac.id ${ }^{1}$, adisup@ee.its.ac.id ${ }^{2}$, haruslg@me.its.ac.id ${ }^{3}$,imam@ep.its.ac.id ${ }^{4}$, \\ mohammadherli@wiraraja.ac.id ${ }^{5}$
}

\begin{abstract}
ABSTRAK
UMKM di Indonesia saat ini sedang berkembang sangat pesat. Berbagai kegiatan dilaksanakan untuk mendorong dan mendukung pengembangan UMKM di semua bidang. UMKM yang telah memiliki kesiapan SDM dan SDA akan sangat berpotensi untuk berkembang lebih cepat.

Dalam analisa peluang UMKM keris di Kabupaten Sumenep, terdapat berbagai kekuatan yang telah dimilikinya. Beberapa peluang kekuatan diantaranya adalah SDA dan SDM. Namun demikian beberapa agenda kegiatan pengembangan masih dapat dilaksanakan guna mendukung lebih cepat berkembangnya UMKM Kersi di Kabupaten Sumenep ini.

Pengembangan pada menejemen promosi dan kesinambungan penerimaan pesanan dapat diupayakan untuk ditingkatkan. Ini akan dapat meningkatkan keberlangsungan saat pra produksi, produksi dan pasca produksi akan lebih terjalin kuat.
\end{abstract}

Kata kunci: keris; kekuatan; potensi; produksi

\section{ABSTRACT}

MSMEs in Indonesia are currently developing very rapidly. Various activities are carried out to encourage and support the development of MSMEs in all fields. MSMEs that have HR and natural resources readiness will have the potential to develop more quickly.

In analyzing the opportunities of the keris MSME in Sumenep Regency, there are various strengths it has. Some of the strength opportunities include natural resources and human resources. However, several agendas of development activities can still be implemented to support the faster development of these MSMEs Keris in Sumenep Regency.

Efforts can be made to improve promotion management and the continuity of order acceptance. This will increase sustainability when pre-production, production and post-production will be more closely intertwined.

Keyword: kris; power; potency; production

\section{PENDAHULUAN}

UMKM Keris di Kabupaten Sumenep telah memiliki nama di hampir seluruh Indonesia. Salah satu keunggulannya adalah kualitas pengerjaan yang sangat baik. Hal ini tentu saja tidak terlepas dari telah ditekuninya kerajinan ini oleh masyarakat di Kabupaten Sumenep tersebut.

Daya dukung lingkungan dan masyarakat sangat berlimpah di sana. Keahlian masyarakat dalam menyelesaikan keris telah berlangsung lama. Sumber daya tenaga ahli perajin juga berasal dari lingkungan sekitar Kabupaten Sumenep. Hal ini menjadi poin-poin penting dapat cepatnya UMKM keris ini akan berkembang. Beberapa solusi menjadi penting untuk menjaga kesinambungan antara proses pra produksi, produksi dan pasca produksi.

Beberapa kajian yang telah dilakukan adalah menggali pemetaan UMKM kerajinan keris Kabupaten Sumenep ini. Hasil dari pemetaan ini selanjutnya dapat dijadikan masukan bagi upaya dalam menyusun strategi-strategi dalam pengembangan UMKM tersebut. 
Menurut studi Mahendra Wardhana (2018), potensi yang dimiliki UMKM kerajinan keris Kabupaten Sumenep telah ada pada semua tahapan pra produksi, produksi dan pasca produksi. Potensi di atas dimiliki secara kuat dan telah berjalan lancar hingga saat ini. Beberapa titik optimalisasi dapat diarahkan pada perkuatan dari upaya-upaya yang telah dilaksanakan saat ini. Upaya ini diantaranya adalah hanya di beberapa agenda pada tiap tahapannya.

Tabel 1. Potensi dan Pengembangannya

\begin{tabular}{|c|c|c|c|}
\hline No & $\begin{array}{l}\text { Faktor } \\
\text { analisa }\end{array}$ & Keunggulan (Potensi) & Kelemahan (bukan potensi) \\
\hline $\mathbf{A}$ & \multicolumn{3}{|c|}{ Pra Produksi } \\
\hline 1 & $\begin{array}{l}\text { Bahan } \\
\text { Baku }\end{array}$ & \begin{tabular}{|lr} 
Bahan baku sangat & mudah \\
didapatkan dan lancar & dalam \\
persediaan bahan bakunya. & \\
\end{tabular} & \\
\hline 2 & $\begin{array}{l}\text { Tanaga } \\
\text { Kerja }\end{array}$ & $\begin{array}{l}\text { Tenaga kerja yang dibutuhkan telah } \\
\text { dapat dipenuhi dan telah memiliki } \\
\text { kecakapan teknis yang memadai. }\end{array}$ & \\
\hline 3 & $\begin{array}{l}\text { Kategori } \\
\text { pesanan }\end{array}$ & $\begin{array}{l}\text { Kemampuan dalam menerima } \\
\text { pesanan keris sampai saat ini telah } \\
\text { dapat dipenuhi dengan baik. Hal ini } \\
\text { dikarenakan kemampuan teknis } \\
\text { perajin sudah sangat baik. }\end{array}$ & \\
\hline 4 & $\begin{array}{l}\text { Koleksi } \\
\text { desain }\end{array}$ & $\begin{array}{l}\text { Desain yang dibuat sudah sangat } \\
\text { beragam dan sangat bagus. Hal ini } \\
\text { menandakan kalau dari sisi desain } \\
\text { tidak menjadikan permasalahan. }\end{array}$ & \\
\hline 5 & $\begin{array}{l}\text { Penerimaa } \\
\mathrm{n} \text { pesanan }\end{array}$ & $\begin{array}{l}\text { Pesanan dalam pembuatan keris saat } \\
\text { ini sangat memadai. }\end{array}$ & $\begin{array}{l}\text { Namun demikian kesinambungan } \\
\text { dalam penerimaan pesanan perlu } \\
\text { dikelola lagi. }\end{array}$ \\
\hline 6 & Keuangan & & $\begin{array}{l}\text { Dapat ditingkatkan dengan } \\
\text { pemberian bantuan keuangan }\end{array}$ \\
\hline
\end{tabular}

Sumber: Mahendra Wardhana (2018)

Dari contoh pendetailan potensi pengembangan UMKM kerajinan keris di Kabupaten Sumenep di tahapan pra produksi menunjukkan bahwa potensi keberlanjutan kerajinan keris di Kabupaten Sumenep sangatlah tinggi nilainya. Potensi ini ditandai dengan keberlanjutan UMKM ini yang telah berlangsung lama dan bertahan dengan baik dalam perjalanannya.

Pada tahapan produksi dan pasca produksi juga memiliki gambaran peluang yang hampir sama dengan tahapan pra produksi. Keunggulan yang berupa peluang harus dimanfaatkan dan dipertahankan dengan baik. Sedangkan kegiatan-kegiatan yang lainnya masih dapat dikembangkan lebih lanjut lagi. Selanjutnya dapat digali kesempatan untuk pengembangannya berupa kegiatan dan instansi yang paling sesuai untuk melaksanakannya.

\section{METODE PENELITIAN}

Penelitian ini dilaksanakan dengan menggabungkan metode observasi dan kualitatif. Metode observasi digunakan untuk mencari data masing-masing peluang yang ada pada tiap tahapannya. Metode ini kemudian akan diperkaya dengan wawancara dengan perajin yang ada. Metode ini memiliki keunggulan yakni lengkapnya data yang dibutuhkan dan kemampuan untuk berkembangnya data berdasarkan informasi di lapangan. Dalam observasi yang 
dilengkapi dengan wawancara tersebut, maka didapatkan beberapa peluang dari UMKM keris di Kabupaten Sumenep ini.

Analisa dilaksanakan setelah penggalian data dari studi lapangan berupa observasi dan wawancara. Dalam analisa ini beberapa hal-hal kegiatan selama tahapan pra produksi, produksi dan pasca produksi akan dianalisa kendala dan keunggulannya.

Hasil analisa pada tahapan studi lapangan selanjutnya akan diolah untuk mendapatkan strategi pengembangannya. Strategi pengembangan akan dapat dicek lagi kesesuaiannya dengan kesinambungan antar tahapannya.

\section{HASIL PENELITIAN DAN PEMBAHASAN}

Penelitian ini difokuskan pada kemungkinan dapat dilaksanakannya strategi pengembangan UMKM pada tiap level kegiatannya. Seperti diketahui, terdapat tiga level kegiatan yakni pra produksi, produksi, dan pasca produksi. Tahapan-tahapan di atas menjadi penting untuk dikaitkan antara satu bagian dengan bagian lainnya.

Fokus di atas dikaitkan dengan pendapat Senapati Nusantara (2017) yang menyatakan bahwa keris sekarang lebih dilihat sebagai barang asesoris dan peninggalan leluhur yang artistik. Dengan demikian, keris memiliki kebutuhan produksi yang menerus dan berkesinambungan. Lebih lanjut mengenai kerajinan keris di Kabupaten Sumenep, menurut Sulaiman B.A. (1980) salah satu daerah penghasil kerajinan Keris di Sumenep adalah Desa Aeng Tong Tong.

Pada tahapan pra produksi, maka faktor-faktor yang penting untuk dianalisa adalah:

1. Bahan baku

2. Tenaga kerja

3. Kategori pesanan

4. Koleksi desain

5. Penerimaan pesanan

6. Keuangan

Sedangkan pada tahapan Produksi, maka faktor-faktor yang penting untuk dianalisa adalah:

1. Peralatan

2. Kemampuan produksi

3. Jadwal produksi

4. Proses produksi

5. Tempat

6. Keuangan

Pada tahapan pasca produksi, maka faktor-faktor yang penting untuk dianalisa adalah:

1. Jumlah pesanan

2. Asal pesanan

3. Promosi

4. Cara penjualan

5. Pembayaran

6. Target pemasaran 




Gambar 1. Proses produksi yang dilaksanakan di UMKM Keris Kabupaten Sumenep Sumber: Wardhana (2019)

Dari berbagai hasil analisa potensi pada UMKM kerajinan keris yang ada, maka didapatkan hasil bahwa kesinambungan antara tahapan pra produksi, produksi dan pasca produksi akan sangat penting untuk saling terkait. Keterkaitan tersebut adalah dikarenakan satu tahapan dengan tahapan lainnya harus berjalan berurutan dan bersinergi.

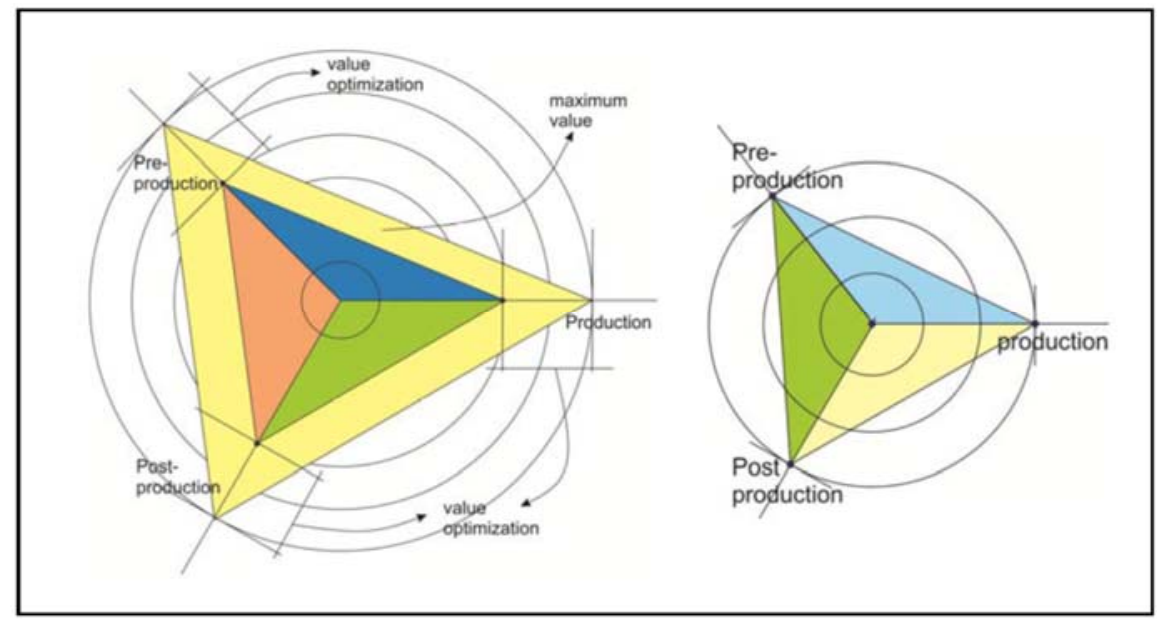

Gambar 2. Potensi UMKM Keris di Kabupaten Sumenep Sumber: Wardhana (2019)

Dari analisa potensi pada UMKM kerajinan keris di Kabupaten Sumenep, maka didapatkan gambaran bahwa terdapat potensi yang sangat besar. Namun demikian masih dapat dikembangkan beberapa hal untuk lebih meningkatkan peluang UMKM ini. Peluang tersebut dapat dilaksanakan oleh beberapa unit instansi yang berkaitan langsung dengan proses yang berlangsung di UMKM tersebut. Beberapa hal yang perlu ditingkatkan adalah berkaitan dengan keberlanjutan produsi dan pemesanan. Lebih detail dan mendalam lagi, maka kegiatan yang dilaksanakan adalah memperkuat networking dan promosi serta pengelolaan pelaksanaan 
produksinya. Guna mendukung kegiatan di atas, maka digunakan kegiatan yang paling sesuai adalah promosi dan manajemen pelaksanaan produksi.

Dua agenda di atas yakni promosi dan manajemen pelaksanaan produksi dilaksanakan dengan sangat sesuai oleh instansi pemerintah daerah yang menaungi UMKM kerajinan keris ini. Kegiatan promosi dilaksanakan guna mendapatkan dan menjaring permintaan dari konsumen secara luas. Promosi ini digunakan dengan menempatkan pada even-even yang paling besar pada agenda pemerintah daerah Kabupaten Sumenep. Even-even tersebut diharapkan langsung dapat mengenalkan kekayaan UMKM tersebut ke masyarakat pendatang dari luar Kabupaten Sumenep. Guna mendapatkan efektifitas dalam kegiatan promosi ke masyarakat luar, maka sangat efektif kalau even-even promosi dilaksanakan di luar Kabupaten Sumenep.

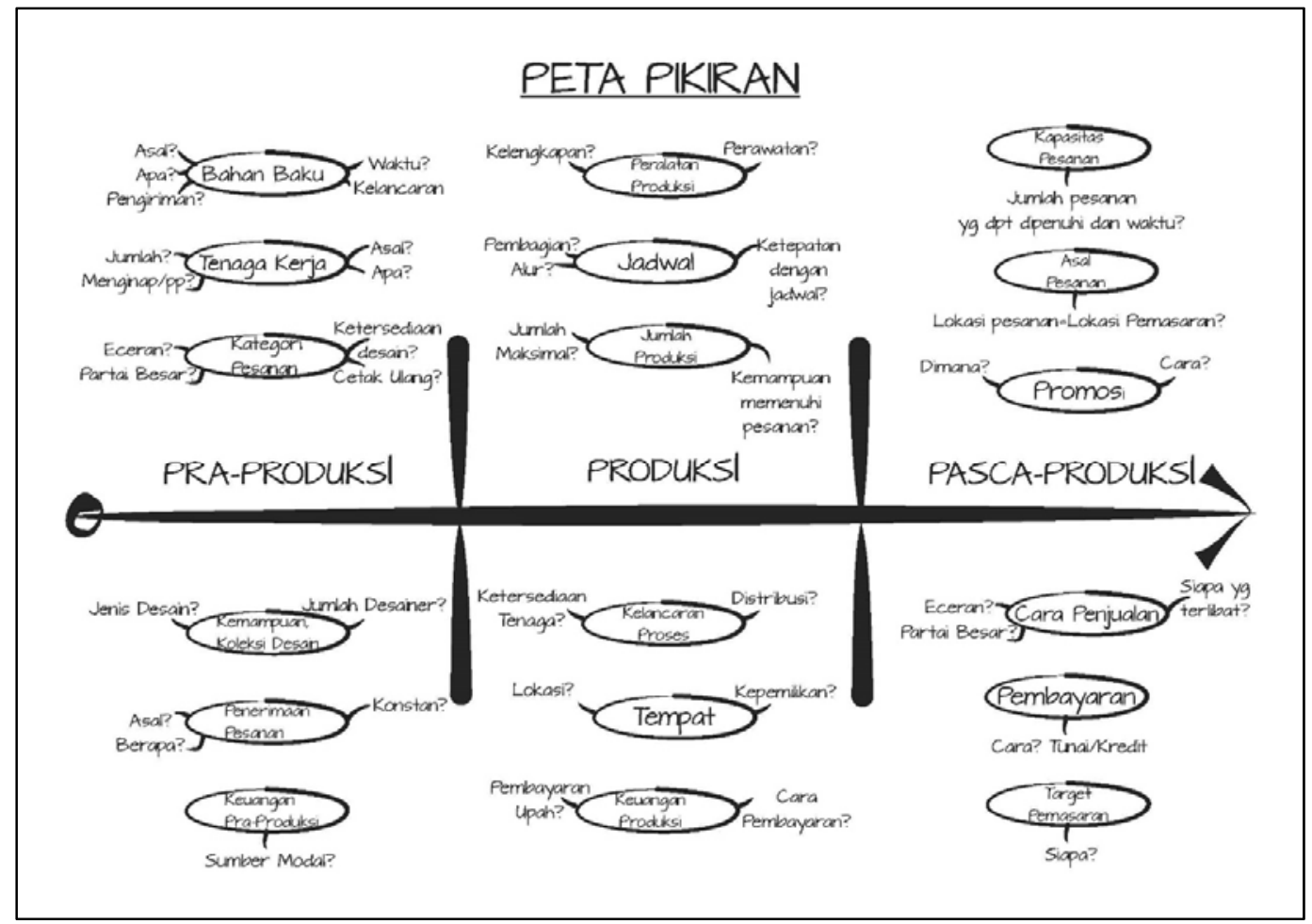

Gambar 3. Peta pikiran penengembangan UMKM Keris di Kabupaten Sumenep Sumber: Wardhana (2019)

Pada kegiatan manajemen pelaksanaan produksi, maka dapat diwujudkan dengan memperkuat pengetahuan dan aplikasi manajemen pelaksanaan di setiap UMKM-nya. Untuk kegiatan ini, maka upgrade dan pendampingan manajemen UMKM menjadi sangat penting untuk dilaksanakan. UMKM akan dapat melaksanakan upgrading melalui mitra yang menguasai manajemen produksi dengan baik. Untuk ini, maka mitra dari usahawan swasta yang telah tertata baik proses produksinya menjadi penting untuk turut membantu perbaikan manajemen proses produksi. Dengan demikian usaha yang diperlukan adalah menyambungkan antara mitra swasta dengan UMKM. Upaya ini yang paling optimal seyogyanya dilaksanakan oleh pemerintah daerah. Penyambungan hubungan antara swasta dengan UMKM ini menjadi sangat penting dilaksanakan secara periodik. Upaya secara periodik ini agar mendapatkan 
kontinuitas (keberanjutan) yang sangat terprogram. Hal ini dapat dirujuk dari proses produksi kerajinan keris menurut Wardhana (2019).

Potensi dan kendala yang dianalisa pada diagram di atas menunjukkan bahwa potensinya jauh memiliki nilai positif yakni bernilai 4 (empat). Nilai ini didapatkan dari setiap kegiatan positif berupa peluang yang ada sebanyak empat kegiatan. Sedangkan nilai kendalanya adalah bernilai 2 (dua) di tiap tahapannya. Nilai ini didapatkan dari adanya dua kegiatan yang masih dapat dioptimalkan lebih luas lagi dalam pengembangannya. Jadi, dengan demikian, nilai keseluruhannya apabila dikembangkan secara maksimal adalah bernilai 6 (enam). Nilai ini akan sangat baik sekali, karena disemua tahapan (pra produksi, produksi, dan pasca produksi) akan didapatkan secara maksimal semuanya.

Arti pengembangan dari nilai empat ke nilai enam ini adalah setiap tahapan akan memerlukan tambahan dua kegiatan yang bernilai prositif. Nilai ini didapatkan dengan mengoptimalkan kegiatan yang masih dirasakan kurang. Kegiatan tersebut, selanjutnya dilaksanakan dengan pendampingan dan secara periodik dalam pelaksanaannya.

\section{KESIMPULAN}

Beberapa kesimpulan penting yang dapat dikembangkan dari analisa mengenai potensi dan hambatannya adalah dengan memperhatikan keberlanjutan produksi UMKM kerajinan keris Kabupaten Sumenep ini. Keberlanjutan ini dengan memperhatikan sisi keberlangsungan pesanan dan kemampuan keberlanjutan pembuatan keris yang telah dipesan oleh pemesan.

Dengan memperhatikan dua faktor pendamping UMKM kerajinan keris Kabupaten Sumenep ini, maka didapatkan optimalisasi bagi instansi yang mendampingi UMKM dalam tahapan ini adalah instansi pemerintah daerah Kabupaten Sumenep dan mitra swasta yang memiliki kemampuan dalam mengelola produksi dengan baik. Instansi pemerintahan khususnya Kabupaten Sumenep menjadi instansi yang paling sesuai dalam pendampingan ini dikarenakan pemerintah daerah sangat mengetahui keadaan dan keperluan pengembangan UMKM kerajinan keris ini.

Upaya yang ditempuh pemerintah daerah dalam mengembangkan UMKM kerajinan keris ini adalah mengadakan promosi yang lebih baik berupa kunjungan dagang dan promosi pengenalan kerajinan keris Kabupaten Sumenep pada konsumen yang baru. Pemetaan konsumen yang baru ini menjadi penting dianalisa pada waktu-waktu mendatang.

\section{DAFTAR PUSTAKA}

Nusantara, Senapati. (2017). Makna dan Fungsi Keris pada Kehidupan orang Jawa. (Online). (http://senapatinusantara.org/makna-dan-fungsi-keris-dalam-kehidupan-orang-jawa/)

Sulaiman. (1980). Seni Ukir Madura. Departemen Pendidikan dan Kebudayaan.

Wardhana, Mahendra. (2018). Pemetaan Potensi UMKM Pengrajin Keris di Kabupaten Sumenep Madura, Laporan akhir penelitian EPI UNET ITS 2018. Tidak diterbitkan.

Wardhana, Mahendra. (2019). Kajian Strategi Pengembangan UMKM Pengrajin Keris di Kabupaten Sumenep Madura, Laporan Akhir Penelitian Antar Perguruan Tinggi ITS 2019. Tidak diterbitkan. 